\title{
The Ownership Structure Influence on the Dividend Distribution Policy: The Case of Listed French Family Firms
}

\author{
Aymen Habib \\ Excelia Group La Rochelle \\ Aymen Ajina \\ Faculty of Economics and Management of Sousse \\ Imene Zarrouki \\ Excelia Group La Rochelle \\ CRIEF EA 2249 \\ Yosra Meddeb \\ Excelia Group La Rochelle \\ TREE-UMR CNRS 6031
}

The usefulness and justification of corporate dividend distribution policies are among the most controversial topics in financial theory. This research aims to shed light on this issue by studying the case of French listed family firms. These companies have a specific governance structure that influences the dividend distribution policy. We examined the impact of the family ownership structure on dividend distribution policy and present empirical study results for a sample of listed French family companies. We explain the dividend distribution policy through the family shareholding structure and the presence of institutional investors and their possible influence. The theoretical framework is the agency relationship. The results show that family ownership positively affects dividend distribution; however, institutional investors have a negative influence.

Keywords: corporate governance, dividend distribution, ownership structure, shareholding family, institutional investors

\section{INTRODUCTION}

Economic news emphasizes the importance of dividend payouts. According to a study carried out by Boursorama in 2017, the dividends paid out worldwide increased by $7.7 \%$, i.e., faster than economic growth (3.6\%). In addition, CAC40 companies distributed 57.4 billion euros in dividends for the 2018 financial year according to the AMF. However, the topic of dividends is one of the most studied and controversial subjects in financial theory. Through the notion of the "dividend puzzle," Black (1976) shows the lack of theoretical and empirical unanimity around the dividend distribution policy. Dividends are an important 
component of profitability and a fundamental element in the market's evaluation of companies. If the market is efficient and without taxes or transaction costs, dividends have no effect on the value of the firm. This is the thesis supported by neoclassical theory, which advocates the neutrality of dividend distribution policy. This position is not unanimously supported by the various theories and explanations proposed to understand its determinants in an imperfect world.

Bhattacharya (1979) and Miller and Rock (1985) show the neutrality of dividend distribution policy by relaxing the assumptions of market efficiency. According to these authors, this neutrality allows investors to better understand a firm's performance and to value it at fair value. Moreover, Easterbrook (1984) and Jensen and Meckling (1976) show the non-neutrality of dividend distribution policy under agency theory. However, agency theory does not offer the same financial predictions for firms with concentrated ownership, as these analyses admit the perfect diffusion of shareholding.

However, in the context of dispersed ownership, shareholders delegate their management rights to managers through an agency agreement. This separation of ownership and control functions creates agency costs because of the divergent objectives of shareholders and managers. Agency conflicts are not limited to the shareholder-manager relationship; they are also seen in the relationship between majority and minority shareholders. The financial literature considers that the holding of power in the hands of a few shareholders can be an effective means of controlling managers. However, this concentration can trigger agency problems between majority and minority shareholders.

Family firms are not immune to this type of conflict (Schulze et al., 2001; Songini et al., 2013). Although several studies support that the presence of a family manager can reduce agency conflict and opportunistic behavior of family managers at the expense of minority shareholders (Dyer, 2018; Villalonga and Amit, 2006; De Massis et al., 2013; Kowalewski et al., 2010), agency conflicts can arise within family firms. Sacristán-Navarro et al. (2011) argue that conflicts of interest can also arise between family shareholders. In addition, conflicts could arise between majority and minority shareholders if they want to protect their own interests.

Agency problems between majority and minority shareholders can be triggered by the impact of shareholder concentration on dividend payments. Research on this topic has been motivated by the differences between Anglo-Saxon and continental European governance systems. This has been partly explained by the variation in legal regimes between systems that advocate investor protection and those that do not. Myers (1977) considers that possible competition between the investing and distributing dividends can be a source of conflict between shareholders and investors. Calvi-Reveyron (2000) argues that the distribution of dividends at the cost of a slowdown in investment increases the risk of nonrepayment by investors. In this context, despite the wealth of studies related to this problem in Anglo-Saxon countries, in France only a few studies contribute to the understanding of this issue. Therefore, the aim of this work is to shed additional light on a topical subject that is still little discussed in France. It is legitimate to question the link between the ownership structure of family businesses in France and the dividend distribution policy within governance.

On a practical level, the results of this research show that among the major players likely to influence the dividend distribution policy of listed French family businesses, the family shareholder and the institutional investor emerge. We shall see that these two types of players, in turn, are predominant according to their importance in corporate governance systems through their effect on the dividend distribution policy.

The aim of this article is to highlight the relationship between dividend distribution and the ownership structure of listed French family companies. The study results show that dividend distribution policy is positively influenced by shareholder concentration. This result reflects a certain behavior on the part of French shareholders, who tend to adopt a generous dividend distribution policy in order to develop a good reputation for their system of governance and to protect the interests of minority shareholders. The results also show that the proportion of institutional investors among the company's shareholders suppresses the level of dividends distributed. These investors provide the market with a guarantee that the interests of minority shareholders will be protected. However, family ownership has a positive dividend payout ratio. 
This result implies that information asymmetry remains significant in this type of structure, which increases the risk of expropriation of private profits.

This article is organized as follows: The first section illustrates the literature linking dividend distribution policy to ownership structure. The second section presents the sample and the methodology used. The third section presents the results and discussion.

\section{LITERATURE REVIEW AND HYPOTHESIS DEVELOPMENT}

\section{Shareholding Structure and Dividend Distribution Policy}

The agency relationship between management and shareholders may give rise to conflicts of interest that generate costs. It seems appropriate to seek to resolve these conflicts or at least to reduce them for the well-being of the company. Jensen and Meckling (1976) argue that the distribution of dividends is one way to reduce agency problems. The distribution of dividends invites managers to seek the funds necessary to maintain the same investment policy. Additional borrowing requires the implementation of an audit and review procedure in the company. In this spirit, the distribution of dividends is an implicit mechanism for shareholders to control the oversight of managers and to know whether they are acting in the firm's interest.

The financial literature also considers that the holding of power in the hands of a few shareholders can be an effective means of controlling management. However, this concentration may trigger agency problems between majority and minority shareholders (McConnell and Servaes, 1990; Mudambi and Nicosia, 1998; Gorton and Schmid, 2000; Morck et al., 2000). Shleifer and Vishny (1997) argue that shareholders are likely to use their power of control to expropriate certain private benefits. The authors assume that the payment of dividends can be an ideal disciplinary mechanism to deal with the risk of expropriation if it guarantees a proportional payment for all majority and minority shareholders.

La Porta et al. (1999) consider that firms operating in civil law countries with weak investor protection, such as France, pay low dividends. This is due to the greater agency problems between controlling shareholders and external shareholders. In customary law countries, investors are better protected and benefit from relatively generous dividend payments. Gomes (2000) also shows that a reputation for good treatment of shareholders characterizes countries with weak legal protection for shareholders. The use of dividends to form such a reputation seems to be the common rule adopted by these countries.

Shleifer and Vishny (1997) agree that the ownership structure appears to be a variable that can have a decisive influence on control of managers because the structure provides the basis for an efficient control system, i.e., an incentive for controllers to perform their duties. Where ownership is concentrated, the dominant shareholders easily and directly control the manager. This structure can reduce agency costs caused by the opportunism of the professional manager and improve performance. Moreover, the dominant shareholders may exercise their discretionary power to the detriment of the interests of minority shareholders (Hamon and Hamon 2001). Dominant shareholders appropriate private profits instead of internalizing and sharing them. The costs of moral hazard are increased (Bebchuk, 1999).

Maury and Pajuste (2002) examine the relationship between the controlling shareholder, agency problems and dividend distribution policy of Finnish companies. Their sample consisted of 131 firms over the period 1995-1999. Their analysis of ownership and control structures shows that the controlling shareholder has an average voting power of $33.2 \%$. The dominant shareholder has a negative influence on the distribution of dividends as it appropriates the private benefits of control. Similarly, Lee and Xiao (2003) argue that the payment of dividends is driven by the motive of expropriation by the controlling shareholder. Their empirical study of a sample of 2,397 firms listed on Chinese stock exchange shows that the probability of paying dividends increases with shareholding concentration. Based on the above, we formulate our first hypothesis:

H1: There is a negative relationship between the controlling family shareholder and the dividend payout ratio.

112 Journal of Leadership, Accountability and Ethics Vol. 18(3) 2021 


\section{Type of Ownership}

Family Ownership

Collins et al. (1996) find that there is a negative relationship between family shareholding and dividend distribution policy. The family-dominated firm has less need to report its performance through dividends. There is large information asymmetry between family members in management positions and minority shareholders. To test the hypothesis that family firms pay low dividends, Kumar (2012) uses a sample of Indian firms over the period 1994-2000. He finds a non-linear relationship between the level of family ownership and the dividend ratio. When family members own a certain threshold of shares, there is a generous distribution of dividends. Above this threshold, the level of distribution declines. If family members hold a larger share of the capital, the opportunities for private profit are greater and more beneficial than generous distributions in the form of dividends. Based on the family shareholding threshold assumption, we put forward the following hypothesis:

H2: There is a positive relationship between family shareholding below the threshold of control and the dividend distribution rate.

\section{Institutional Investors' Ownership}

In the French market, institutional investors have seen a rapid growth in their presence in the capital structure of large listed companies. Given these investors' weight in the firm, they have an incentive to invest in its control by holding seats on the board of directors, and by investing in research and information processing to protect their investments. Thus, agency costs can be limited by control activities undertaken by institutional investors (Bathala et al., 1994; Carleton et al., 1998).

Grinstein and Michaely (2005) show that the proportion of shares held by institutional investors is positively associated with the dividend payout rate, due to the supervisory functions performed by institutional investors. Furthermore, Short et al. (2002) use ownership structure data for 211 UK firms between 1988 and 1992. They find that the presence of institutional investors in the ownership structure of firms has a positive impact on dividend distribution policy.

Institutional investors provide a guarantee of protection for the interests of minority shareholders, especially when the ownership is concentrated (Ginglinger and L'her, 2006). However, several studies have shown that either there is no relationship between the presence of institutional investors and the dividend payout ratio, or a significant negative relationship is observed (Badrinath et al., 1996; Del Guercio, 1996; Gompers et al., 2003). Thus, based on the role of institutional investors as a steering mechanism in the corporate governance system rather than a mere control and monitoring mechanism, we formulate the following hypothesis:

H3: There is a negative relationship between the presence of institutional investors and the dividend payout rate.

\section{SAMPLE AND METHODOLOGY}

\section{Sampling and Data Collection}

The study is based on a sample of 98 family-owned companies listed in the French market over a twoyear period from 2016 to 2017, i.e., 196 observations. To ensure the consistency of the sample, we eliminated financial companies because their dividend distribution policies, governance systems and notion of debt differ from managerial companies. To identify family firms, we used Morck et al. (2000) definition: A family firm is "a firm controlled either by an entrepreneur or by an heir at the $20 \%$ threshold." Similarly, La Porta et al. (1999) define a family firm in terms of the control rights concentrated in the hands of a family or an individual at the $20 \%$ threshold. Therefore, we chose to designate as "family-owned" any firm where the founding family still holds more than $20 \%$ of the equity. This threshold seemed to reflect the minimum held by families in family-owned companies in the French market. In view of the above, the sample is reduced to 44 companies, i.e., 88 observations. 
We collected the sample of listed French family businesses from the Diane database and accounting and stock market data from the Thomson Reuters database. Data on shareholder structure were extracted from annual reports and the Dafsalien database. In addition, following the example of La Porta et al. (1999) study, we used the ownership structure from 2016 for the year 2017. The ownership structure of companies remains unchanged in the short term. We used SPSS22 software to conduct an empirical study.

TABLE 1

DESCRIPTION OF THE LISTED FAMILY BUSINESSES

\begin{tabular}{|l|l|l|}
\hline French stock market & Number of companies & Percentage \\
\hline Compartment A & 9 & 20.4 \\
\hline Compartment B & 12 & 27.3 \\
\hline Compartment C & 23 & 52.3 \\
\hline Total & $\mathbf{4 4}$ & $\mathbf{1 0 0}$ \\
\hline
\end{tabular}

\section{Measurement of Variables}

Dividend Distribution

The dividend payout ratio is equal to the ratio of total dividends to net income. This ratio makes it possible to estimate the trade-off that the firm makes between the distribution and retention of profits. The distribution is determined considering the objective of maximizing shareholder wealth.

\section{Concentration of Family Ownership}

This variable is binary, taking the value 1 if the percentage of capital held by the family exceeds $50 \%$, 0 otherwise.

\section{Family Ownership}

It represents the percentage of shares held by family members. The $F A M$ variable refers to the percentage held by family shareholders. This percentage is greater than $20 \%$.

\section{Institutional Ownership}

This is the percentage of shares held by institutional investors. The variable INST represents the percentage of shares held by institutional shareholders.

\section{Control Variables}

The shareholding structure is not the only factor that can explain the dividend distribution policy. The theoretical and empirical literature points to other factors. These include indebtedness, the value of free cash flows and the size and performance of the company.

\section{Indebtedness}

Some researchers, such as Crutchley and Hansen (1989), investigate the decision to distribute dividends in conjunction with other financial decisions such as indebtedness. Debt has a negative impact on the distribution of dividends because of restrictions imposed by creditors that try to limit the payment of dividends to avoid the risk of bankruptcy of the companies to which they have granted loans. We expect that debt negatively affects the dividend payout ratio. It is measured as the ratio of total debt to total assets.

\section{Free Cash Flow}

Jensen's (1986) hypothesis suggests that firms with more growth opportunities have the lowest free cash flows and therefore, distribute low dividends to reduce agency costs. Thus, we anticipate a positive relationship between free cash flows and the level of dividend distribution. The FCF ratio is measured by the ratio of the net income less dividends plus depreciation (amortization) to the total assets of the firm. 
Size

This is a proxy for agency costs, which are expected to be high in large firms. Several authors, including Rozeff (1982), show that the relationship between firm size and the firm's payout ratio is positive, as large firms have easier access to capital markets, which reduces the firm's reliance on internal funds. Size is measured by the total assets.

\section{Performance}

Several researchers, such as Claessens et al. (2002) and Denis and McConnell (2003), detect a positive relationship between dividend payments and firm performance. They show that the payment of dividends can contribute to improving firm performance by reducing agency conflicts. We measure performance with the market-to-book ratio, which measures the stock market performance of companies and expresses the increase in their share price following its high valuation by investors on the stock market. Shome and Singh (1995) argue that this ratio is a reasonable proxy for a company's investment opportunities. Moreover, the expected sign between the MTB ratio and the dividend payment is positive.

TABLE 2

DEFENITIONS AND MEASUREMENT OF VARIABLES

\begin{tabular}{|c|c|c|}
\hline Variable & Definition & Measure \\
\hline $\begin{array}{l}\text { Dependent variable } \\
\text { DIV }\end{array}$ & Dividends distribution rate & Dividends/net income \\
\hline Independent variables & & \\
\hline CFAM & $\begin{array}{l}\text { Concentration of controlling } \\
\text { family shareholders }\end{array}$ & $\begin{array}{l}\text { Binary variable which takes the value } 1 \\
\text { if the percentage of capital held by the } \\
\text { family exceeds } 50 \%, 0 \text { otherwise. }\end{array}$ \\
\hline$F A M$ & Family shareholders & $\begin{array}{l}\text { Percentage of capital held by family } \\
\text { shareholder }\end{array}$ \\
\hline INST & $\begin{array}{l}\text { Institutional investor } \\
\text { shareholding }\end{array}$ & $\begin{array}{l}\text { Percentage of capital held by } \\
\text { institutional investors }\end{array}$ \\
\hline $\begin{array}{l}\text { Control variables } \\
D E B T\end{array}$ & Indebtedness & The ratio of total debt to total assets \\
\hline$F C F$ & Free cash-flows & $\begin{array}{l}\text { The ratio of net income less dividends } \\
\text { and plus depreciation (amortization) to } \\
\text { total assets of the firm }\end{array}$ \\
\hline SIZE & Size of the company & Total assets \\
\hline MTB & Market to Book & $\begin{array}{l}\text { The ratio of the company's market } \\
\text { capitalization to its equity capital }\end{array}$ \\
\hline
\end{tabular}

\section{Methodology}

Our method consists of regressing the model's determinants of the ownership structure and the control variables with the endogenous dividend distribution variable in order to estimate the impact of the ownership structure on the distribution policy and to test the research hypotheses.

The model to be tested is as follows:

$$
\begin{aligned}
& D I V_{i t}=\alpha_{0}+\alpha_{1} F A M_{i t}+\alpha_{2} C F A M_{i t}+\alpha_{3} I N S T_{i t}+\alpha_{4} M T B_{i t}+ \\
& \alpha_{5} S_{I Z E_{i t}}+\alpha_{6} F C F_{i t}+\alpha_{7} D E B T_{i t}+\varepsilon_{i t}
\end{aligned}
$$


$D I V$ : distribution of dividends.

FAM: percentage of capital held by family shareholders.

CFAM: binary variable which takes the value 1 if the percentage of capital held by the family exceeds $50 \%$, 0 otherwise.

INST: percentage of capital held by institutional investors.

$M T B$ : stock market performance of the company measured by the market to book ratio.

$S I Z E$ : the size of the company measured by the total assets.

$F C F$ : the company's free cash flow.

$D E B T$ : the company's indebtedness.

$\mathcal{E}$ : the residual term.

\section{RESULTS AND DISCUSSION}

\section{Descriptive Analysis}

The descriptive statistics of the sample are summarized in Table 3. The ownership structure of listed French companies is characterized by moderately concentrated family shareholding: $47.11 \%$ of the capital of the family firms in the sample is held by family shareholders. In terms of the type of shareholder, the percentage of shares held by institutional investors averages $18.12 \%$. This result shows that institutional investors are increasingly participating in shareholding of listed French family firms. Despite the emergence of this new category of shareholders, the share of family capital remains high among listed companies, averaging $65.08 \%$, and that half of the companies in the sample are family owned.

TABLE 3

DESCRIPTIVE STATISTICS

\begin{tabular}{|l|l|l|l|l|l|l|}
\hline & N & Minimum & Maximum & Average & $\begin{array}{l}\text { Standard } \\
\text { deviation }\end{array}$ & Kurtosis \\
\hline DIV & 88 & 0.00 & 43.26 & 17.3898 & 14.30712 & 0.067 \\
\hline $\boldsymbol{F A M}$ & 88 & 20 & 96.11 & 47.1167 & 20.61358 & -0.815 \\
\hline $\boldsymbol{I N} \boldsymbol{V S T}$ & 88 & 0.00 & 52.09 & 18.1298 & 13.98555 & -0.185 \\
\hline $\boldsymbol{M T B}$ & 88 & 0.2 & 10.51 & 1.6463 & 1.28683 & 25.571 \\
\hline $\boldsymbol{S I Z E}$ & 88 & 1.79 & 9.92 & 5.3575 & 2.13741 & -0.669 \\
\hline $\boldsymbol{F C F}$ & 88 & -938 & 2357 & 45.2736 & 326.71658 & 30.644 \\
\hline $\boldsymbol{D E B T}$ & 88 & 0.00 & 33018.00 & 1442.8644 & 5151.5016 & 29.018 \\
\hline $\boldsymbol{C F A M}$ & 44 & 50.55 & 96.11 & 65.0814 & 11.46462 & 0.833 \\
\hline
\end{tabular}

DIV: the dividend distribution rate calculated as the ratio between the amount of dividends and net profit, FAM: the percentage of shares held by family shareholders, INST: the percentage of capital held by institutional investors, MTB: the company's stock market performance ratio, SIZE: the size of the company is measured by the total assets, FCF: the value of free cash flows, DEBT: measures the company's total debts, CFAM: measures the number of companies under family control.

Another bivariate analysis was conducted to test for the possible presence of a multi-collinearity problem between the explanatory variables. The matrix of partial correlations reveals multi-collinearity between some of the variables examined. To avoid it, we performed linear regression across several models by separating the variables, and the results were almost identical. This leads us to conclude that there is no problematic multi-collinearity. 
TABLE 4

CORRELATION MATRIX

\begin{tabular}{|c|c|c|c|c|c|c|c|c|}
\hline & $D I V$ & $F A M$ & CFAM & INST & $M T B$ & SIZE & $F C F$ & $D E B T$ \\
\hline$D I V$ & 1 & & & & & & & \\
\hline$F A M$ & $0.363^{* *}$ & 1 & & & & & & \\
\hline & 0.001 & & & & & & & \\
\hline \multirow[t]{2}{*}{ CFAM } & $0.321^{* *}$ & $0.876^{* *}$ & 1 & & & & & \\
\hline & 0.002 & 0.001 & & & & & & \\
\hline \multirow[t]{2}{*}{ INST } & $-0.260^{*}$ & $-0.314^{* *}$ & -0.168 & 1 & & & & \\
\hline & 0.014 & 0.003 & 0.119 & & & & & \\
\hline \multirow[t]{2}{*}{$M T B$} & -0.164 & -0.034 & -0.184 & -0.181 & 1 & & & \\
\hline & 0.126 & 0.753 & 0.085 & 0.092 & & & & \\
\hline \multirow[t]{2}{*}{ SIZE } & $0.259^{*}$ & -0.17 & -0.163 & -0.012 & 0.017 & 1 & & \\
\hline & 0.015 & 0.114 & 0.129 & 0.911 & 0.876 & & & \\
\hline \multirow[t]{2}{*}{$F C F$} & -0.012 & -0.083 & -0.061 & 0.064 & -0.026 & 0.182 & 1 & \\
\hline & 0.914 & 0.444 & 0.574 & 0.554 & 0.811 & 0.09 & & \\
\hline \multirow[t]{2}{*}{$D E B T$} & 0.009 & -0.124 & -0.159 & $0.325^{* *}$ & -0.177 & 0.436 & 0.356 & 1 \\
\hline & 0.937 & 0.251 & 0.14 & 0.002 & 0.098 & 0.000 & 0.001 & \\
\hline
\end{tabular}

DIV: the dividend distribution rate calculated as the ratio between the amount of dividends and the net profit, FAM: the percentage of shares held by the family shareholders, CFAM: binary variable which takes the value 1 if the percentage of capital held by the family exceeds $50 \%, 0$ otherwise, INST : the percentage of capital held by institutional investors, MTB: the company's stock market performance ratio, SIZE: the size of the company is measured by the total assets, FCF: the value of free cash flows, DEBT: measures the company's total debt.

* The correlation is significant at the 0.05 level (bilateral).

** The correlation is significant at the 0.01 level (bilateral).

TABLE 5

MULTIPLE REGRESSION

\begin{tabular}{|l|l|l|l|l|}
\hline \multicolumn{2}{|l|}{} & \multicolumn{2}{l|}{ Model 1 } & \multicolumn{2}{l|}{ Model 2 } \\
\cline { 2 - 5 } & $\mathbf{t}$ & Sig. & t & Sig. \\
\hline (Constante) & 1.291 & 0.201 & 1.705 & 0.092 \\
FAM & 1.855 & 0.067 & 3.558 & 0.001 \\
CFAM & -0.977 & 0.283 & & \\
INST & -1.274 & 0.206 & -2.077 & 0.041 \\
MTB & -2.05 & 0.044 & -2.088 & 0.04 \\
SIZE & 3.348 & 0.001 & 3.358 & 0.001 \\
FCF & -0.092 & 0.927 & -0.123 & 0.903 \\
DEBT & -0.775 & 0.44 & -0.731 & 0.467 \\
\hline
\end{tabular}

DIV: the dividend distribution rate calculated as the ratio between the amount of dividends and the net profit, FAM: the percentage of shares held by the family shareholders, CFAM: binary variable which takes 
the value 1 if the percentage of capital held by the family exceeds $50 \%, 0$ otherwise, INST : the percentage of capital held by institutional investors, MTB: the company's stock market performance ratio, SIZE: the size of the company is measured by the total assets, FCF: the value of free cash flows, DEBT: measures the company's total debt.

\section{Multivariate Analysis and Discussion}

Table 5 shows that the relationship between the family controlling interest and the dividend payout ratio is negative but not statistically significant. The latter is not consistent with the theoretical and empirical work that asserts family controlling ownership increases the probability of expropriation behavior by minority shareholders through the payment of low dividends (Faccio et al., 2001; Maury and Pajuste, 2002; Gugler and Yurtoglu, 2003). Firms controlled by family members distribute low dividends because they are not the only means of remuneration (Collins et al., 1996). In this type of company, the use of indirect dividends (other remuneration in the form of current account interest) is less costly than the dividend distribution policy. As a result, the expropriation of minority interests in family businesses is more pronounced. However, the company dominated by family shareholders has less need to report on its performance through dividends. There is clearly information asymmetry between the latter and external shareholders, which has a negative impact on the dividend payout ratio. In our context, this implies that a dividend payment to minority shareholders creates a certain reputation for the governance system of French listed companies with controlling family shareholders. Thus, the first hypothesis, which states that there is a negative relationship between the concentration of the controlling family ownership and the dividend distribution policy, is not supported.

The relationship between family shareholding, which does not reach the level of majority control, and the dividend distribution policy, is positive and significant. The presence of family shareholders in listed family companies tends to encourage minority investors through dividend distribution, and thus, minimize agency conflicts and information asymmetry in corporate governance. This result supports the second hypothesis, which states that there is a positive relationship between family shareholding that does not reach the control threshold and the dividend distribution rate.

Moreover, several scholars argue that one way to control executives is to pay high dividends to limit the executives' aberrant use of funds. In a study of 507 Korean firms over the period 1999-2004, Cook and Jeon (2006) concur. However, that study distinguishes between foreign and domestic institutional investors; moreover, it adds that foreign investors' shareholding is associated with a wider distribution of dividends. The results of this research are consistent with those of Grinstein and Michaely (2005) for U.S. companies. For the present study, the dividend ratio declines with the proportion of institutional investors in the capital stock which is shown in Table 5. This relationship can be explained by the fact that these investors seek to ensure the permanent monitoring of management in order to take advantage of the opportunities that arise for the company. Institutional investors demand the proper conduct of corporate governance and of the management team. Thus, the third hypothesis that there is a negative relationship between the presence of institutional investors and the dividend payout ratio is supported.

Among other things, the dividend distribution policy is associated with a statistically significant negative stock market performance. Thus, according to the present results, dividend distribution reflects a negative stock market performance for listed family businesses. Size has a positive and statistically significant impact on dividend distribution. This can be explained by the maturity that the company can acquire as its size increases. However, the results show that the decision to distribute dividends is negatively but not statistically significantly associated with the presence of free cash flows, which contradicts Jensen's (1986) hypothesis of free cash flows. The latter stipulates that a firm with high private profits is obliged to increase its dividends to alleviate the problem of the manager's aberrant use of funds in unprofitable investments. This suggests that in France, dividends are not used as a means of controlling the funds made available to managers. Finally, indebtedness is a substitute control mechanism for the dividend distribution policy (Jensen, 1986; Agrawal and Jayaraman, 1994). Firms with little debt should, all other things being equal, distribute more dividends. 


\section{CONCLUSION}

The theoretical and empirical literature has dealt with the notion of power distribution within the family firm, focusing on the impact of the concentration of ownership in the hands of family members on the dividend distribution policy. The analysis of the ownership structure and its impact on the dividend distribution policy has been approached in the literature from two angles. The first relates to the effect of the concentration of ownership on the payment of dividends based on expropriation behavior and on the various levers that can strengthen the controlling power of majority shareholders. The second is based on the analysis of the influence of certain types of shareholders on the dividend distribution policy based on the argument that each shareholder has different objectives and ambitions depending on their category.

The results of this study show that the dividend distribution policy is negatively influenced by controlling family shareholders. This result implies that information asymmetry remains important in this type of structure, which increases the risk of expropriation of private profits and reduces the use of dividends as a means of signaling. Moreover, family shareholding that does not reach the threshold of majority control has a statistically significant positive effect on the dividend distribution policy. This result reflects a certain behavior on the part of French shareholders, who tend to adopt a generous dividend distribution policy in order to develop a good reputation for their system of governance and for protecting the interests of minority shareholders. Analysis of the impact of the ownership structure according to the type of shareholder shows that the proportion of institutional investors among shareholders has a negative influence on the dividend distribution policy of the family businesses in the sample. These investors provide a guarantee of corporate governance for the market.

\section{REFERENCES}

Agrawal, A., \& Jayaraman, N. (1994). The dividend policies of all-equity firms: A direct test of the free cash flow theory. Managerial and Decision Economics, 15(2), 139-148.

Badrinath, S.G., Kale, J.R., \& Ryan H.E. (1996). Characteristics of common stock holdings of insurance companies. Journal of Risk and Insurance, pp. 49-76.

Bathala, C.T., Moon, K.P., \& Rao, R.P. (1994). Managerial ownership, debt policy, and the impact of institutional holdings: An agency perspective. Financial Management, pp. 38-50.

Bebchuk, L.A. (1999). A rent-protection theory of corporate ownership and control. National Bureau of Economic Research.

Bhattacharya, S. (1979). Imperfect information, dividend policy, and "the bird in the hand" fallacy. The Bell Journal of Economics, pp. 259-270.

Black, F. (1976). The pricing of commodity contracts. Journal of Financial Economics, 3(1-2), 167-179.

Calvi-Reveyron, M. (2000). Le capitalisme familial, dans un contexte français, induit-il moins de dividendess que les autres formes d'actionnariat? Finance, Contrôle, Stratégie, 3(1), 81-116.

Carleton, W.T., Nelson, J.M., \& Weisbach, M.S. (1998). The Influence of Institutions on Corporate Governance through Private Negotiations: Evidence from TIAA-CREF. The Journal of Finance, 53(4), 1335-1362.

Claessens, S., Djankov, S., Fan, J.P., \& Lang, L.H. (2002). Disentangling the incentive and entrenchment effects of large shareholdings. The Journal of Finance, 57(6), 2741-2771.

Collins, M.C., Saxena, A.K., \& Wansley, J.W. (1996). The role of insiders and dividend policy: A comparison of regulated and unregulated firms. Journal of Financial and Strategic Decisions, 9(2), 1-9.

Cook, D.O., \& Jeon, J.Q. (2006). Foreign ownership, domestic ownership, and payout policy. Working paper.

Crutchley, C.E., \& Hansen, R.S. (1989). A test of the agency theory of managerial ownership, corporate leverage, and corporate dividends. Financial Management, pp. 36-46.

De Massis, A., Frattini, F., \& Lichtenthaler, U. (2013). Research on technological innovation in family firms: Present debates and future directions. Family Business Review, 26(1), 10-31. 
Del Guercio, D. (1996). The distorting effect of the prudent-man laws on institutional equity investments. Journal of Financial Economics, 40(1), 31-62.

Denis, D.K., \& McConnell, J.J. (2003). International corporate governance. Journal of Financial and Quantitative Analysis, 38(1), 1-36.

Dyer, W.G. (2018). Are Family Firms Really Better? Examining the 'Family Effect' on Firm Performance. Family Business Review, 31(2), 240-248.

Easterbrook, F.H. (1984). Two agency-cost explanations of dividends. The American Economic Review, 74(4), 650-659.

Faccio, M., Lang, L.H., \& Young, L. (2001). Dividends and expropriation. American Economic Review, pp. 54-78.

Ginglinger, E., \& L'her, J.F. (2006). Ownership structure and open market stock repurchases in France. European Journal of Finance, 12(1), 77-94.

Gomes, A. (2000). Going public without governance: managerial reputation effects. The Journal of Finance, 55(2), 615-646.

Gompers, P., Ishii, J., \& Metrick, A. (2003). Corporate governance and equity prices. The Quarterly Journal of Economics, 118(1), 107-156.

Gorton, G., \& Schmid, F. (2000). Class struggle inside the firm: a study of German codetermination. National Bureau of Economic Research.

Grinstein, Y., \& Michaely, R. (2005). Institutional holdings and payout policy. The Journal of Finance, 60(3), 1389-1426.

Gugler K., \& Yurtoglu B.B. (2003). Corporate governance and dividend pay-out policy in Germany. European Economic Review, 47(4), 731-758.

Hamon, J., \& Hamon, J.J. (2001). La répartition des droits de vote, leur exercice et l'efficacité économique. Revue d'Economie Financière, pp. 175-209.

Jensen, M.C. (1986). Agency cost of free cash flow, corporate finance, and takeovers. American Economic Review, 76(2).

Jensen, M.C., \& Meckling, W.H. (1976). Theory of the firm: Managerial behavior, agency costs and ownership structure. Journal of Financial Economics, 3(4), 305-360.

Kowalewski, O., Talavera, O., \& Stetsyuk, I. (2010). Influence of family involvement in management and ownership on firm performance: Evidence from Poland. Family Business Review, 23(1), 45-59.

Kumar, J. (2012). Corporate governance and dividends payout in India. Journal of Emerging Market Finance, 5(1), 15-58.

La Porta, R., Lopez-de-Silanes, F., \& Shleifer, A. (1999). Corporate ownership around the world. The Journal of Finance, 54(2), 471-517.

Lee, C., \& Xiao, X. (2003). Cash dividends in China: Liquidating, expropriation and earnings management. Paper presented at EFMA Annual Meeting Paper.

Maury, C.B., \& Pajuste, A. (2002). Controlling shareholders, agency problems, and dividend policy in Finland. LTA, 1(2), 15-45.

McConnell, J.J., \& Servaes, H. (1990). Additional evidence on equity ownership and corporate value. Journal of Financial Economics, 27(2), 595-612.

Miller, M.H., \& Rock, K. (1985). Dividend policy under asymmetric information. The Journal of Finance, 40(4), 1031-1051.

Morck, R., Nakamura, M. \& Shivdasani, A. (2000). Banks, Ownership Structure, and Firm Value in Japan. The Journal of Business, 73(4), 539-567.

Mudambi, R., \& Nicosia, C. (1998). Ownership structure and firm performance: Evidence from the UK financial services industry. Applied Financial Economics, 8(2), 175-180.

Myers, S.C. (1977). Determinants of corporate borrowing. Journal of Financial Economics, 5(2), $147-$ 175.

Rozeff, M. (1982). Growth, beta and agency costs as determinants of dividend payout ratios. Journal of Financial Research, 5(3), 249-259. 
Sacristán-Navarro, M., Gómez-Ansón, S., \& Cabeza-García, L. (2011). Family ownership and control, the presence of other large shareholders, and firm performance: Further evidence. Family Business Review, 24(1), 71-93.

Schulze, W.S., Lubatkin, M.H., Dino, R.N., \& Buchholtz, A.K. (2001). Agency relationships in family firms: Theory and evidence. Organization Science, 12(2), 99-116.

Shleifer, A., \& Vishny, R.W. (1997). A survey of corporate governance. The Journal of Finance, 52(2), 737-783.

Shome, D.K., \& Singh, S. (1995). Firm value and external blockholdings. Financial Management, pp. 314.

Short, H., Keasey, K., \& Duxbury, D. (2002). Capital structure, management ownership and large external shareholders: A UK analysis. International Journal of the Economics of Business, 9(3), 375-399.

Songini, L., Gnan, L., \& Malmi, T. (2013). The role and impact of accounting in family business. Journal of Family Business Strategy, 4(2), 71-83.

Villalonga, B., \& Amit, R. (2006). How do family ownership, control and management affect firm value? Journal of Financial Economics, 80(2), 385-417. 